\title{
Association between periodontal condition and subgingival microbiota in women during pregnancy: a longitudinal study
}

\author{
Priscila Viola BORGO1, Viviane Aparecida Arenas RODRIGUES ${ }^{2}$, Alfredo Carlos Rodrigues FEITOSA ${ }^{1}$, Karla Correa \\ Barcelos XAVIER ${ }^{1}$, Mario Julio AVILA-CAMPOS ${ }^{2}$
}

\author{
1- Dentistry Clinic, Federal University of Espírito Santo, Vitória, ES, Brazil. \\ 2- Anaerobe Laboratory, Department of Microbiology, University of São Paulo, São Paulo, SP, Brazil.
}

Corresponding address: Mario Julio Avila-Campos - Phone/Fax: +55-11-3091-7344/7354 - e-mail: mariojac@usp.br

Submitted: May 5, 2014 - Modification: September 8, 2014 - Accepted: September 14, 2014

\begin{abstract}
$\mathrm{O}$ bjective: In this study, the gingival conditions and the quantitative detection for Aggregatibacter actinomycetemcomitans, Fusobacterium nucleatum, Porphyromonas gingivalis and Prevotella intermedia in pregnant women were determined. Material and Methods: Quantitative determinations of periodontal bacteria by using a SyBr green system in women during pregnancy were performed. Women at the $2^{\text {nd }}$ and $3^{\text {rd }}$ trimesters of pregnancy and non-pregnant women were included in this study. A. actinomycetemcomitans was observed in high numbers in women at the $2^{\text {nd }}$ and $3^{\text {rd }}$ trimesters of pregnancy with a significant difference $(p<0.05)$. F. nucleatum and P. intermedia were also observed in high levels. Results and Conclusion: Our results show that pregnant women are more susceptible to gingivitis, and the presence of $A$. actinomycetemcomitans in subgingival biofilm might be taken into account for the treatment of periodontal disease.
\end{abstract}

Keywords: Gingivitis. Periodontal disease. Pregnancy.

\section{NTRODUCTI ON}

Periodontal diseases are chronic polymicrobial infections determined by the interaction between microorganisms and immune, environmental, behavioral and/or hereditary factors, causing an inflammatory response of the periodontal tissues ${ }^{14,18}$. This disease affects individuals of different ages and it is characterized by a chronic tissue-destructive inflammation and dental attachment loss.

The pathogenesis of periodontal disease is a result of the accumulation of bacterial species in subgingival biofilm, particularly by gram-negative anaerobic and microaerophilic bacteria, such as Porphyromonas gingivalis, Prevotella intermedia, Prevotella nigrescens, Tannerella forsythia, Treponema denticola, Fusobacterium nucleatum, Aggregatibacter actinomycetemcomitans, and Campylobacter rectus ${ }^{7}$.

Studies have shown a relationship between the periodontal disease and systemic changes in pregnant women, such as diabetes, cardiovascular and lung diseases, and pregnancy complications, as well as hormonal alterations during pregnancy causing gingival inflammation ${ }^{9}$. The periodontal diseases have been implicated as risk factors for adverse pregnancy outcomes, such as prematurity and low birth weight ${ }^{11,12}$, as well as the presence of different periodontal bacteria, such as $A$. actinomycetemcomitans, $P$. gingivalis, $P$. nigrescens, and $C$. rectus in oral microbiota from pregnant women ${ }^{10,20}$.

Gingival alterations associated to the biofilm formation during pregnancy are often observed, and this may increase the severity of gingivitis. In addition, variations in the oral microbiota and cellular metabolism have been observed, as well as an increase in estrogens levels, such as progesterone, affecting the vascular permeability, producing edema, and increasing the gingival fluid $^{21,23}$.

The identification of microbial agents producing severe periodontal diseases and the efficacy of suitable therapeutic method might help to the 
maintenance of the periodontal health and it might be important to the development of better programs aimed to pregnant women and newborn health.

In this study, we hypothesized that there is a possible association between the periodontal condition and periodontal bacteria in women at the $2^{\text {nd }}$ and $3^{\text {rd }}$ trimesters of pregnancy, and it was evaluated.

\section{MATERI AL AND METHODS}

\section{Participants}

Twenty three pregnant women from 18 to 35 years old were evaluated, and nine of them were selected in accordance to the inclusion criteria. The participants were recruited at the National Health System of Vila Nova de Colares (Serra, ES, Brazil), and all of them had medical prenatal and dental care. Nine non-pregnant women aged from 18 to 35 years old belonging to an evangelical community and that did not use any hormonal contraceptive method were also included as controls. Pregnant women were at the $2^{\text {nd }}$ (between $15^{\text {th }}$ and $26^{\text {th }}$ weeks) and $3^{\text {rd }}$ trimester (between $30^{\text {th }}$ and $36^{\text {th }}$ weeks) of gestation, and gestational age was confirmed by ultrasound. All participants displaying at least 15 teeth, excluding third molars, were included in this study. Women with chronic diseases, smokers, alcohol dependency, use of systemic antibiotics in the last three months, use of prophylactic antibiotics for periodontal examination in the last six months, or extensive prosthetic rehabilitation, were excluded. In the course of the sample collections, 11 pregnant women were treated with antibiotics (10 with urinary infection and one with sinusitis), and three women did not attend the scheduled appointments, and they were excluded. All participants signed an informed consent form, approved by the Ethics Committee of the Federal University of Espírito Santo, Vitória, ES, Brazil (Protocol No. 259/10).

The demographic and socio-economic data and the medical and dental history were also collected. The demographic data were: time of pregnancy (first collection at $21^{\text {st }}$ weeks and second collection at $33^{\text {rd }}$ weeks), no use of anti-conceptive, ethnic in pregnant women ( 2 white, 3 black, 4 mulatto), and non-pregnant ( 5 white, 1 black, 3 mulatto). Socio economic level in pregnant belonged to 1 class $B$, 6 class $C, 2$ class $D$, and in non-pregnant belonged to 6 class B, 3 class $\mathrm{C}$.

The clinical examination was conducted by a single trained dentist. Clinical evaluation was performed on all teeth (except third molars) and at six sites per tooth by using North Carolina periodontal probes (PC-PUNC 15, Hu-Friedy manufacturing Inc., Chicago, IL, USA). In all the pregnant women, the clinical monitoring was not affected by any discomfort or adverse effect commonly observed during pregnancy, such as nausea, vomiting, weakness, or blood pressure alterations.

The highest score to the evaluated clinical parameters were registered, as follows: visible plaque index (VPI), gingival bleeding index (GBI); probing depth (PD); clinical attachment level (CAL); and bleeding on probing (BOP). Periodontitis was defined as the presence of four or more teeth with one or more sites of $P D \geq 4.0 \mathrm{~mm}$ and $C A L \geq 3.0$ $\mathrm{mm}$, and being localized in two or three teeth and generalized into four or more teeth. Gingivitis was defined when PD $\leq 3.0 \mathrm{~mm}$ and $C A L \leq 2.0 \mathrm{~mm}$ in two to five teeth or at least one site with bleeding on probing; and periodontal healthy when PD $\leq 2.0$ $\mathrm{mm}$ and $C A L \leq 2.0 \mathrm{~mm}$, and no site with gingival bleeding $^{2-4}$.

\section{Sample collection and processing}

Supragingival biofilm was removed with sterile gauze and subgingival biofilm samples were collected from the mesial buccal or mesial vestibular of the first or second molar by using two sterilized paper points (No. 30 Tanari, Tanariman Ind Ltd, Manacapuru, AM, Brazil) inserted into gingival crevice for 30 seconds. Twenty-seven subgingival samples from nine women during the $2^{\text {nd }}$ ( 9 samples) and $3^{\text {rd }}$ ( 9 samples) semesters of pregnancy and from nine non-pregnant women ( 9 samples) were collected. The paper points were transferred into a tube containing $300 \mu$ l of TE buffer (Invitrogen, Invitrogen do Brasil Ltd, São Paulo, SP, Brazil), and stored at $-80^{\circ} \mathrm{C}$.

\section{Bacterial determination by qPCR}

Bacterial DNA was obtained by using a phenolchloroform method ${ }^{6}$ and stored at $-80^{\circ} \mathrm{C}$ until use. DNA from A. actinomycetemcomitans ATCC 29523, F. nucleatum ATCC 25586, P. gingivalis ATCC 33277, and P. intermedia ATCC 25611 were used to determine the standard curves, showing a correlation coefficient $\left(R^{2}\right)>0.99$ and efficiency from $90 \%$ to $110 \%$. Quality, integrity, and quantity of DNA were analyzed by NanoDrop spectrophotometer (NanoDrop 2000 Thermo Scientific, Thermo Fischer Scientific Inc, Wilmington, DE, USA), and $10 \mu \mathrm{l}$ of each DNA sample was also checked on $1 \%$ agarose gel.

DNA amplifications were performed in a thermal cycler Rotor Gene 6000 with Software 1.7 Series (Corbett, Corbett Life Science, Mortlake, NSW, Australia), by using species-specific primers based on the sequence of the $16 \mathrm{~S}$ rRNA (Figure 1) and with a Sybr Green system. Amplifications were performed in final volumes of $20 \mu \mathrm{l}$, containing 2 X Sybr Green master mix (Promega, Promega Corporation, Madison, WI, USA), $100 \mu \mathrm{M}$ each 
primer, and 2 ng DNA. Amplification reactions for all microorganisms were performed in duplicate, as follows: 1 cycle of $95^{\circ} \mathrm{C}$ ( $\left.2 \mathrm{~min}\right), 40$ cycles of $95^{\circ} \mathrm{C}$ (45 sec) and $60^{\circ} \mathrm{C}(2 \mathrm{~min})$, and suitable annealing temperature (Figure 1). The species-specific primers and quantitative determination conditions are shown in Figure 1. Following amplification, melting temperature analysis of PCR products was performed to determine the specificity of the PCR, and master mix without DNA was used as negative control.

\section{Statistical analyses}

The statistical analyses were performed by using the GraphPad Prism, Version 5.0.

\section{RESULTS}

The periodontal characteristics of the women during pregnancy are shown in Table 1 . It is possible to note that at $2^{\text {nd }}$ trimester of pregnancy, all the parameters, IPV, ISG, PS, CAL, and SS showed lower values than at the $3^{\text {rd }}$ trimester. In addition, the non-pregnant women showed values $(\leq 2$ $\mathrm{mm}$ ) considered as normal. None of the women showed periodontitis. Our results show that, during pregnancy, the gingival inflammation is increased (Table 1).

All the four periodontal bacteria were detected in both of the analyzed pregnancy periods, as well as in non-pregnant women. In Table 2 , it is possible to note the number of copies for each microorganism in pregnant and non-pregnant women. It was observed at the $2^{\text {nd }}$ trimester of pregnancy that the values of copy numbers ranged from $1.49 \times 10$ to $5.50 \times 10^{8}$ for $A$. actinomycetemcomitans, from 0 to $2.60 \times 10^{5}$ for $F$. nucleatum, from 0 to $7.48 \times 10^{2}$ for $P$. intermedia, and from 0 to $2.81 \times 10^{2}$ for $P$. gingivalis. The bacterial detection at the $3^{\text {rd }}$ trimester of pregnancy was similar to the $2^{\text {nd }}$ trimester, as follows: from 0 to $8.25 \times 10^{8}$ for $A$. actinomycetemcomitans; from 0 to $1.90 \times 10^{5}$ for $F$. nucleatum; from 0 to $2.24 \times 10^{2}$ for $P$. intermedia; and from 0 to $4.43 \times 10$ for $P$. gingivalis. Interestingly, in non-pregnant women, F. nucleatum (from 0 to $3.73 \times 10^{5}$ ) and $\mathrm{P}$. gingivalis (from 0 to $1.46 \times 10^{2}$ ) were the most prevalent.

The presence of $A$. actinomycetemcomitans in pregnant women at the $2^{\text {nd }}$ and $3^{\text {rd }}$ trimester compared to the non-pregnant group showed statistically significant values $(p<0.05)$. A randomized longitudinal observation was followed for women during the $2^{\text {nd }}$ and $3^{\text {rd }}$ trimesters of pregnancy. It allowed the evaluation of possible changes in both periodontal status and microbiota during pregnancy, when hormonal variations are observed $^{1,8}$.

\begin{tabular}{|c|c|c|c|c|}
\hline Microorganism & Oligonucleotides & Amplicon & Melting & Reference \\
\hline & 5' & size (bp) & temperature $\left({ }^{\circ} \mathrm{C}\right)$ & \\
\hline $\begin{array}{c}\text { Aggregatibacter } \\
\text { actinomycetemcomitans }\end{array}$ & $\begin{array}{l}\text { CTTACCTACTCTTGACATCCGAA } \\
\text { ATGCAGCACCTGTCTCAAAGC }\end{array}$ & 262 & 60 & $\begin{array}{l}\text { Kuboniwa, et al. }{ }^{19} \\
\text { (2004) }\end{array}$ \\
\hline Fusobacterium nucleatum & $\begin{array}{l}\text { CTTAGGAATGAGACAGAGATG } \\
\text { TGATGGTAACATACGAAAGG }\end{array}$ & 120 & 56 & $\begin{array}{l}\text { Periasamy, et al. }{ }^{25} \\
\qquad(2009)\end{array}$ \\
\hline Porphyromonas gingivalis & $\begin{array}{c}\text { ACCTTACCCGGGATTGAAATG } \\
\text { CAACCATGCAGCACCTACATAGAA }\end{array}$ & 83 & 57 & $\begin{array}{l}\text { Kuboniwa, et al. }{ }^{19} \\
(2004)\end{array}$ \\
\hline Prevotella intermedia & $\begin{array}{c}\text { CGTGGACCAAAGATTCATCGGTGGA } \\
\text { CCGCTTTACTCCCCAACAAA }\end{array}$ & 258 & 55 & $\begin{array}{c}\text { Okamoto, et al. }{ }^{24} \\
(1999)\end{array}$ \\
\hline
\end{tabular}

Figure 1- Species-specific oligonucleotides used for the quantitative detection

Table 1- Periodontal conditions of women at the $2^{\text {nd }}$ and $3^{\text {rd }}$ trimesters of pregnancy

\begin{tabular}{|c|c|c|c|c|c|}
\hline \multirow[t]{2}{*}{ Pregnancy } & \multicolumn{5}{|c|}{ Clinical parameters (values) } \\
\hline & \multirow[t]{2}{*}{ VPI (\%) } & \multirow[t]{2}{*}{ GBI (\%) } & \multirow{2}{*}{$\begin{array}{c}\text { PD }(\mathrm{mm}) \\
\text { Mean } \pm S D\end{array}$} & \multirow{2}{*}{$\begin{array}{l}\text { CAL }(\mathrm{mm}) \\
\text { Mean } \pm S D\end{array}$} & \multirow[t]{2}{*}{ BOP (\%) } \\
\hline & & & & & \\
\hline $2^{\text {nd }}$ trimester & 60 & 26 & $2.48 \pm 0.93^{a}$ & $2.37 \pm 0.90^{a}$ & 46 \\
\hline $3^{\text {rd }}$ trimester & 65 & 52 & $2.71 \pm 1.0^{\mathrm{b}}$ & $2.50 \pm 0.92^{b}$ & 62 \\
\hline Non-pregnant & 21 & 5 & $1.94 \pm 0.80$ & $1.93 \pm 0.79$ & 17 \\
\hline
\end{tabular}


Table 2- Quantitative determination of four periodontal bacteria in subgingival biofilm from women at the $2^{\text {nd }}$ and $3^{\text {rd }}$ trimester of pregnancy and non-pregnant women

\begin{tabular}{|c|c|c|c|}
\hline \multirow[t]{2}{*}{ Microorganism } & \multicolumn{2}{|c|}{$\begin{array}{l}\text { pregnant women } \\
\text { (No. of copies) }\end{array}$} & \multirow[t]{2}{*}{$\begin{array}{l}\text { non-pregnant women } \\
\text { (No. of copies) }\end{array}$} \\
\hline & Second trimester & Third trimester & \\
\hline \multicolumn{4}{|c|}{ Aggregatibacter actinomycetemcomitans } \\
\hline $\mathrm{P} 1$ & $2.58 \mathrm{E}+10^{2}$ & $2.93 \mathrm{E}+10$ & 0 \\
\hline P2 & $6.05 \mathrm{E}+10$ & $2.45 \mathrm{E}+10$ & 0 \\
\hline P3 & $3.79 \mathrm{E}+10^{3}$ & $8.25 \mathrm{E}+10^{8}$ & 0 \\
\hline P4 & $1.62 \mathrm{E}+10$ & 0 & 0 \\
\hline P5 & $5.37 \mathrm{E}+10$ & $6.65 \mathrm{E}+10^{4}$ & 0 \\
\hline P6 & $1.49 \mathrm{E}+10$ & $5.05 \mathrm{E}+10^{3}$ & 0 \\
\hline P7 & $3.15 \mathrm{E}+10^{2}$ & $1.73 \mathrm{E}+10^{5}$ & 0 \\
\hline P8 & $6.17 \mathrm{E}+10^{4}$ & $3.08 \mathrm{E}+10^{4}$ & 0 \\
\hline P9 & $5.50 \mathrm{E}+10^{8}$ & $9.05 \mathrm{E}+10^{4}$ & 0 \\
\hline \multicolumn{4}{|c|}{ Fusobacterium nucleatum } \\
\hline $\mathrm{P} 1$ & $4.81 \mathrm{E}+10$ & 0 & 0 \\
\hline P2 & 0 & 0 & 0 \\
\hline P3 & $2.98 \mathrm{E}+10^{2}$ & $3.63 \mathrm{E}+10^{2}$ & $3.90 \mathrm{E}+10^{4}$ \\
\hline P4 & 0 & $8.75 \mathrm{E}+10^{4}$ & $6.99 \mathrm{E}+10^{2}$ \\
\hline P5 & 0 & $1.90 \mathrm{E}+10^{5}$ & $1.06 \mathrm{E}+10^{3}$ \\
\hline P6 & $3.68 \mathrm{E}+10$ & $6.91 \mathrm{E}+10$ & $2.52 \mathrm{E}+10^{3}$ \\
\hline P7 & 0 & $9.26 \mathrm{E}+10^{2}$ & $3.73 E+10^{5}$ \\
\hline P8 & $5.56 \mathrm{E}+10^{4}$ & $1.08 \mathrm{E}+10^{5}$ & $4.36 \mathrm{E}+10$ \\
\hline P9 & $2.60 \mathrm{E}+10^{5}$ & $2.64 \mathrm{E}+10^{3}$ & 0 \\
\hline \multicolumn{4}{|l|}{ Prevotella intermedia } \\
\hline $\mathrm{P} 1$ & $1.83 \mathrm{E}+10^{2}$ & 0 & $5.76 \mathrm{E}+10$ \\
\hline P2 & 0 & 0 & 0 \\
\hline P3 & 0 & $4.62 E+10$ & 0 \\
\hline P4 & $1.74 \mathrm{E}+10$ & 0 & $1.51 \mathrm{E}+10^{2}$ \\
\hline P5 & 0 & $2.75 \mathrm{E}+10$ & 0 \\
\hline P6 & $3.22 \mathrm{E}+10$ & $7.75 \mathrm{E}+10$ & 0 \\
\hline P7 & 0 & 0 & 0 \\
\hline P8 & $2.98 \mathrm{E}+10$ & $2.24 \mathrm{E}+10^{2}$ & 0 \\
\hline P9 & $7.48 \mathrm{E}+10^{2}$ & 0 & 0 \\
\hline \multicolumn{4}{|c|}{ Porphyromonas gingivalis } \\
\hline $\mathrm{P} 1$ & 0 & 0 & 0 \\
\hline P2 & 0 & 0 & $3.15 E+10$ \\
\hline P3 & 0 & 0 & 0 \\
\hline P4 & 0 & 0 & 0 \\
\hline P5 & 0 & $1.02 \mathrm{E}+10$ & 0 \\
\hline P6 & 0 & $4.43 \mathrm{E}+10$ & 0 \\
\hline P7 & 0 & 0 & $1.46 \mathrm{E}+10^{2}$ \\
\hline P8 & $2.81 \mathrm{E}+10^{2}$ & $2.95 \mathrm{E}+10$ & 0 \\
\hline P9 & $1.18 \mathrm{E}+10$ & 0 & $8.01 \mathrm{E}+10$ \\
\hline
\end{tabular}




\section{SCUSSI ON}

Since during pregnancy, women present nausea, vomiting, weakness, blood pressure alterations, hyperventilation, dyspnea, and edema, clinical monitoring becomes exceedingly difficult, as well as their participation ${ }^{8}$, but in this study, these clinical symptoms did not influence our results.

Molecular methods are currently available for typing and subtyping of periodontopathogens, such as $P$. gingivalis, but they can vary in efficiency and in amount of required labor ${ }^{5}$. Bacterial cultures are used to identify putative anaerobic pathogens from destructive periodontal disease, but can be somewhat cumbersome and expensive. Polymerase chain reaction ( $P C R$ ) has been used for direct identification of periodontal pathogens from subgingival samples and for elucidating the role of specific bacteria in the periodontal disease due to the ability to accurately detect bacterial species from mixed populations ${ }^{27}$.

In this study, a real-time PCR method was used to quantify the copies' numbers of four microorganisms in subgingival microbiota from pregnant and non-pregnant women. In addition, studies have shown the presence of periodontal bacteria by using different detecting methods, such as DNA-DNA hybridization or culture of the oral microbiota from pregnant women, but no association between pregnancy and periodontal disease has been demonstrated ${ }^{25,29}$; however, our results showed a significant relationship with the presence of $A$. actinomycetemcomitans among pregnant women at second and third trimester, and it might be important. The four microorganisms evaluated are considered some of the most important in the development of periodontal diseases, and for this reason they were selected.

Since paper points were used for collection of the subgingival samples in bacterial detection, they have proven to be the most reliable method for bacterial detection from crevicular fluid. Traditional methods of bacterial isolation and identification may limit the bacterial recovery due to the lack or absence of viable cells and growth requirements ${ }^{30}$.

An increase of the gingival inflammation was observed particularly between the $2^{\text {nd }}$ and $3^{\text {rd }}$ trimesters of pregnancy, showing statistically significant values $(p<0.05)$. A similar increase in VPI, GBI, BOP, PD, and CAL values was also observed when pregnant and non-pregnant women were compared. These observations are similar to other studies ${ }^{13,28}$. In addition, a severe gingival inflammation ( $\mathrm{GBI}=52 \%$ ) during the $3^{\text {rd }}$ trimester of pregnancy was observed, in accordance with Tilakaratne, et al. ${ }^{28}$ (2000).

The exacerbation of gingival inflammation in pregnant women is clinically and histologically well documented, but its etiology has not been clearly established. Potential mechanisms have been proposed, including alterations in the vascular permeability, immune system, and subgingival biofilm ${ }^{17,26}$. However, there is little data regarding the subgingival microbiota composition during pregnancy. However, it is known that hormonal variation may promote overgrowth of pathogenic bacteria responsible for gingival inflammation ${ }^{22}$.

Studies have shown a high prevalence of $P$. intermedia and $P$. gingivalis at the $2^{\text {nd }}$ trimester of pregnancy due to progesterone and/or estradiol being present in high concentrations, which contribute to bacterial growth ${ }^{15,16}$. Some studies have reported that pregnancy-associated gingivitis is accompanied by an increase in the cell numbers of $P$. intermedia ${ }^{1}$, while others have shown no significant difference in $P$. intermedia numbers during the $2^{\text {nd }}$ and $3^{\text {rd }}$ trimesters of pregnancy ${ }^{23}$. In this study, $P$. intermedia were observed in higher levels compared to $\mathrm{P}$. gingivalis. The inconsistent results in the literature regarding the oral bacteria associated with the onset of periodontal diseases during pregnancy can be explained by the different methodology used in each study ${ }^{13,20}$.

A high incidence of $F$. nucleatum during the $2^{\text {nd }}$ $(77.7 \%)$ and $3^{\text {rd }}(88.8 \%)$ trimester of pregnancy, as well as in non-pregnant women (88.8\%), was observed, and it can be explained by the fact that this microorganism is commonly found in subgingival biofilm, and due to its ability of co-aggregation with other bacteria, such as $P$. gingivalis. On the other hand, the presence of $P$. gingivalis in most of the non-pregnant women suggests that its mere presence is not associated with the initiation or progression of periodontal disease strictly enough, and that other factors, such as bacterial virulence and host immune response, may also be important.

Since a small number of participants was evaluated, it is difficult to generalize to other populations; however, no bias concerning the clinical samples collection was observed, and the common symptoms observed during pregnancy had no influence on our results.

Our results show that pregnant women are more susceptible to gingivitis, and that the presence of A. actinomycetemcomitans in subgingival biofilm might be taken into account for the treatment of periodontal disease, as well as for the monitoring and prophylactic guidance on the oral health of these patients during pregnancy, particularly in late gestation.

\section{ACKNOWLEDGEMENTS}

The authors thank Ms. Marcia Harumi Fukugaiti for her technical support. This study was supported 


\section{by a grant from CAPES-PROCAD/PNPD-2009 and} FAPESP 10/52417-4.

\section{REFERENCES}

1- Adriaens LM, Alessandri R, Spörri S, Lang NP, Persson GR. Does pregnancy have an impact on the subgingival microbiota? J Periodontol. 2009;80:72-81.

2- Ainamo J, Bay I. Problems and proposals for recording gingivitis and plaque. Int Dent J. 1975;25:229-35.

3- Armitage G. Development of a classification system for periodontal diseases and conditions. Ann Periodontol. 1999;4:1-6. 4- Armitage G. Periodontal diagnoses and classification of periodontal diseases. Periodontol 2000. 2004;34:9-21.

5- Ashimoto A, Chen C, Bakker I, Slots J. Polymerase chain reaction of 8 putative periodontal pathogens in subgingival plaque of gingivitis and advanced periodontitis lesions. Oral Microbiol Immunol. 1996;11:266-73.

6- Avila-Campos MJ, Sacchi CT, Whitney AM, Steigerwalt AG, Mayer LW. Arbitrarily primed-polymerase chain reaction for identification and epidemiologic subtyping of oral isolates of Fusobacterium nucleatum. J Periodontol. 1999;70:1202-8.

7- Barak S, Oettinger-Barak O, Machtei EE, Sprecher H, Ohel G. Evidence of periodonpathogenic microorganisms in placentas of women with preeclampsia. J Periodontol. 2007;78:670-6.

8- Carrillo-de-Albornoz A, Figuero E, Herrera D, BasconesMartínez A. Gingival changes during pregnancy: II. Influence of hormonal variations on the subgingival biofilm. J Clin Periodontol. 2010;37:230-40.

9- Davenport ES, Williams CE, Sterne JA, Sivapathasundram V, Fearne JM, Curtis MA. The East London study of maternal chronic periodontal disease and preterm low birth weight infants: study design and prevalence data. Ann Periodontol. 1998;3:213-21.

10- Emmatty R, Mathew JJ, Kuruvilla J. Comparative evaluation of subgingival plaque microflora in pregnant and non-pregnant women: a clinical and microbiologic study. J Indian Soc Periodontol. 2013;17:47-51.

11- Gibbs RS. The relationship between infections and adverse pregnancy outcomes: an overview. Ann Periodontol. 2001;6:15363.

12- Gomez R, Romero R, Edwin SS, David C. Pathogenesis of preterm labor and preterm premature rupture of membranes associated with intraamniotic infection. Infect Dis Clin North Am. 1997; 1:135-76.

13- Gürsoy M, Pajukanta R, Sorsa T, Könönen E. Clinical changes in periodontium during pregnancy and post-partum. J Clin Periodontol. 2008;35:576-83.

14- Haffajee AD, Socransky SS. Microbial etiological agents of destructive periodontal diseases. Periodontol 2000. 1994;5:78111.

15- Jonsson R, Howland BE, Bowden GH. Relationship between periodontal health, salivary steroids and Bacteroides intermedius in males, pregnant and non-pregnant women. J Dent Res. 1988;67:1062-9.
16- Kornman KS, Loesche WJ. The subgingival microbial flora during pregnancy. J Periodontal Res. 1980;15:111-22.

17- Kornman KS, Loesche WJ. Effects of estradiol and progesterone on Bacteroides melaninogenicus and Bacteroides gingivalis. Infect Immun. 1982;35:256-63.

18- Kornman KS, Page RC, Tonetti MS. The host response to the microbial challenge in periodontitis: assembling the players. Periodontol 2000. 1997;14:33-53.

19- Kuboniwa M, Amano A, Kimura KR, Sekine S, Kato S, Yamamoto $Y$, et al. Quantitative detection of periodontal pathogens using real-time polymerase chain reaction with TaqMan probes. Oral Microbiol Immunol. 2004;19:168-76.

20- Machado FC, Cesar DE, Assis AV, Diniz CG, Ribeiro RA. Detection and enumeration of periodontopathogenic bacteria in subgingival biofilm of pregnant women. Braz Oral Res. 2012;26:443-9.

21- Markou E, Eleana B, Lazaros T, Antonios K. The influence of sex and steroid hormones on gingiva of women. Open Den $\mathrm{J}$. 2009;3:114-9.

22- Mascarenhas P, Gapski R, Al-Shammari K, Wang HL. Influence of sex hormones on the periodontium. J Clin Periodontol. 2003;30:671-81.

23- Offenbacher $S$, Jared HL, O'Reilly PG, Wells SR, Salvi $\mathrm{GE}$, Lawrence HP, et al. Potential pathogenic mechanisms of periodontitis associated pregnancy complications. Ann Periodontol. 1998;3:233-50.

24- Okamoto M, Maeda N, Kondo K, Leung KP. Hemolytic and hemagglutinating activities of Prevotella intermedia and Prevotella nigrescens. FEMS Microbiol Lett. 1999;178:299-304.

25- Periasamy S, Kolenbrander PE. Aggregatibacter actinomycetemcomitans builds mutualistic biofilm communities with Fusobacterium nucleatum and Veillonella species in saliva. Infect Immun. 2009; 77:3542-51.

26- Raber-Durlacher JE, van Steenbergen TJ, dan der Velden $U$, de Graaff J, Abraham-Inpijn L. Experimental gingivitis during pregnancy and post-partum: clinical, endocrinological, and microbiological aspects. J Clin Periodontol. 1994;21:549-58.

27- Siqueira JF Jr, Rôças IN. Polymerase chain reaction-based analysis of microorganisms associated with failed endodontic treatment. Oral Surg Oral Med Oral Pathol Oral Radiol Endod. 2004;97:85-94.

28- Tilakaratne A, Soory M, Ranasinghe AW, Corea SM, Ekanayake SL, Silva M. Periodontal disease status during pregnancy and 3 months post-partum, in rural population of Sri-Lankan women. J Clin Periodontol. 2000;27:787-92.

29- Urbán E, Terhes G, Radnai M, Gorzó I, Nagy E. Detection of periodontopathogenic bacteria in pregnant women by traditional anaerobic culture and by a commercial molecular genetics method. Anaerobe. 2010;16:283-8.

30- van Steenbergen TJ, Timmerman MF, Mikx FHM, de Quincey G., van der Weijden GA, van de Velden $U$, et al. Discrepancy between culture and DNA probe analysis for the detection of periodontal bacteria. J Clin Periodontol. 1996;23:955-9. 